\title{
Ticari İşletmelerin Tüzel Kişiliğe Sahip Olmasının Sonuçları: İslam Ekonomisi Açısından Bir Değerlendirme
}

\section{Consequences of the Legal Personality of Commercial Entities: An Evaluation from the Perspective of Islamic Economics}

\author{
Harun ŞENCAL ${ }^{1}$ (1)
}

\section{ÖZ}

Bu çalışmanın amacı sermaye birikimini sağlayarak kapitalist sistemin ortaya çıkmasında önemli rolü bulunan kurumlardan biri olan tüzel kişilik kurumunu İslam ekonomisi açısından eleştirel bir değerlendirmeye tabi tutmaktır. İslam ekonomisinin öngördüğü dayanışma üzerine kurulu olan toplumsal ilişkilerin modern toplumlarda görülen bireyselleşme ile beraber zayıflamasına rağmen asıl olumsuz etkinin sınırsız kâr amacıyla kurulmuş olan ticari tüzel kişiliğe sahip şirketlerin sınırlı sorumluluk sahibi olmalarının getirdiği avantajları kullanarak kapitalist piyasa sisteminde birçok ilişkiyi metalaştırması olduğunu iddia etmekteyiz. Bunun ötesinde, tüzel şirketlerin rasyonel karar mekanizmaları dahilinde en verimli ve düşük maliyetli kâr elde etme yollarını tercih etmelerinden dolayı, toplumdaki maddi eşitsizliği artırmaya ve borca dayalı finansal araçların yaygınlaşmasına yol açmaktadır. Ayrıca, tüzel şirketler yatııımdaki ağırlıklarını reel sektörden ziyade finansal alana kaydırarak finansal kapitalizmin gelişmesinde önemli rol oynamaktadırlar. Diğer bir ifadeyle, finansal kapitalizmin yol açtığı krizlerde ve diğer toplumsal yıkımlarda düzenleme ve denetleme eksikliği gibi arızî sorunlar da etkili olsa da gündeme getirilmeyen önemli bir husus ticari tüzel kişiliklerin varlığı ve kapitalist sistem içerisinde onlara yüklenen misyon olarak sınırsız kâr elde etme hedefidir.

Anahtar kelimeler: İslam ekonomisi, Tüzel kişilik, Finansallaşma JEL Sınıflaması: G23, 016, P12, P51

\footnotetext{
ABSTRACT

This study aims to critically evaluate the institution of a legal personality from the perspective of Islamic economics. The legal personality of commercial entities plays an integral role in the emergence of the capitalist system. This system, in turn, is characterized by capital accumulation. We argue that although the social relations based on the solidarity envisaged by Islamic economics have weakened with the individualization of modern societies, the primary negative effect of individualization has been the commodification of several services provided by solidarity among the members of society in the capitalist market system.
}

1Dr. Öğr. Üyesi, İstanbul 29 Mayıs Üniversitesi, İktisadi ve İdari Bilimler Fakültesi, Ekonomi Anabilim Dal, İstanbul, Türkiye

ORCID: H.Ş. 0000-0003-3617-8954

Sorumlu yazar/Corresponding author: Harun ŞENCAL,

İstanbul 29 Mayıs Üniversitesi, İktisadi ve İdari Bilimler Fakültesi, Ekonomi Anabilim Dalı, İstanbul, Türkiye

E-posta/E-mail: harun.sencal@gmail.com

Başvuru/Submitted: 13.11.2021

Revizyon Talebi/Revision Requested: 17.12.2021

Son Revizyon/Last Revision Received: 22.12.2021

Kabul/Accepted: 24.12 .2021

Atıf/Citation: Sencal, H. (2021). Ticari işletmelerin tüzel kişiliğe sahip olmasının sonuçları: İslam ekonomisi açısından bir değerlendirme. İstanbul iktisat Dergisi - Istanbul Journal of Economics, 71(2), 367-394. https://doi.org/10.26650/ISTJECON2021-1023078 
Typically, such a system has spurred the practice of leveraging the limited liability of commercial legal entities to earn unlimited profits. Furthermore, because corporations prefer earning profits by selecting the most efficient and cost-effective approaches developed by means of rational decision mechanisms, it leads to the increase of material inequality in society and the expansion of debt-based financial instruments. In addition, corporations move investments from the real sector to the financial field, therefore playing a significant role in the development of financial capitalism. In other words, incidental problems such as lack of regulation and supervision are effective in regulating the situation in the wake of the crises caused by financial capitalism and other social adversities; however, a pertinent issue that remains overlooked is the existence of commercial legal entities and the goal of obtaining unlimited profit, which has emerged as the mission imposed on these legal entities within the capitalist system.

Keywords: Islamic economics, Legal personality, Financialization

JEL Classification: G23, 016, P12, P51

\section{EXTENDED ABSTRACT}

According to the basic principles of Islamic economics, an economic system should promote social solidarity and human wellbeing, prioritize the sharing of profits and losses over interest-based financial instruments, and envisage a just and equitable financial system. However, due to the changes having taken place in the modern period, these basic principles have not been adequately realized. The individualization of modern society has acted as a primary agent of such societal changes. Although the degree of individualization varies among countries, premodern solidarity has been compromised significantly due to such large-scale individualization. Owing to such transformation, activities previously fulfilled through social solidarity are now governed by welfare state institutions and the market system. Furthermore, the existence of a legal personality facilitates the dominance of the market, curtails the benefits offered by the financial system to the real economy, and causes social inequality. Commercial entities with legal personalities operate with the goal of earning unlimited profit by leveraging limited liabilities. Such an objective contributes to the development of financial capitalism and an acute shortage of materials; moreover, it raises the volume of debt-based financial instruments. This study aims to critically evaluate, from the perspective of Islamic economics, the institution of legal personality, a phenomenon that plays an essential role in the emergence of the capitalist system that, in turn, facilitates capital accumulation.

We argue that financial crises and other such social adversities caused by financial capitalism stem primarily from the existence of commercial legal entities 
and the goal of unlimited profit as the mission imposed on them within the capitalist system, rather than incidental problems, such as lack of regulation and supervision. Hence, the legal personality exerts a significant influence on the financialization of the economy. The important assertion is that in the current scenario, it would be a rational decision for companies to pursue profits without considering the welfare of society, possess limited liabilities, and exhibit behaviors that might result in negative consequences. Although Islamic scholars have justified the validity of legal personality in Islamic law by referring to the mosque, waqf and state institutions, we argue that such an analogy not be used when evaluating commercial legal personalities. This is because the institutions referenced to legitimize the existence of the legal personality are either established for worship or as a means for Muslims to attain salvation (falah). For this reason, a controversial issue in Islamic law today is the status of the legal personality of corporations, which, as opposed to the legal personality in Islamic law, was established with the goal of obtaining unlimited profit, facilitating capital accumulation, and mitigating company owners' risks.

For this reason, as claimed by Timur Kuran, it is true that Muslim societies had not developed commercial legal entities; however, such absence of commercial legal entities was not owing to a shortcoming of Muslim societies but because of the establishment of "commercial legal entities" was deemed impossible by the Islamic morality that governs Muslim societies. Kuran's basic assumption is that capital accumulation is essential for material growth in all societies. This modern understanding, which claims to be a universal truth, has been challenged, particularly in the post-modern period. Questions such as, "Should material and spiritual growth and development coexist with Islamic moral values?" and "If so, how can this harmony be accomplished?" are subjects that require research in reference to the basic sources of Islamic economics. The scope of this study is to demonstrate the incompatibility of the Islamic morality with the current economic system, which assumes that capital accumulation is a universally inevitable phenomenon and legitimizes the existence of the institution of legal personality as a means for achieving this accumulation. Such incompatibility results from the social consequences of the legal personality. It is argued that existence of the legal 
personality leads to an increase in financialization as opposed to facilitating actual production. Ultimately, it promotes individualism and contributes to the diminishment of essential solidarity and cooperation among individuals. 


\section{Giriş}

Modern öncesinde toplumun içine gömülü (embedded) olarak varlığını sürdüren iktisadi ilişkiler, endüstriyel devrim ile beraber piyasa sisteminin ilkeleri tarafindan belirlenmeye başlamıştır (Polanyi, 2010). Böylece, toplumdaki ilişki ve kurumları belirleyen din ve aile gibi yapıların kurumsal mantıkları tarafından şekillenen (Thornton \& Ocasio, 2008) iktisadi ilişkiler, piyasa sisteminin devamı için gerekli olan bir dönüşüme uğrayarak, toplumu piyasa sistemine uygun hale getirmiştir (Polanyi, 2010). Bunun sonuçlarından biri, bir meta olarak yaratılmamış olan emek, toprak ve para başta olmak üzere toplumun birçok unsurunun kapitalist sistemin varlığını sürdürebilmesi için metaya dönüşerek sisteme uygun hale gelmesidir (Polanyi, 2010). Bu dönüşümler sayesinde, kapitalist sistemin varlığı için gerekli olan bireylerin sınırsız kâr arzusuna sahip olması ve birikmiş sermaye oluşması gerçekleşmeye başlamıştır (Wallerstein, 2014). Sınırsız kâr arzusu motivasyonuyla üretim yapılan endüstriyel kapitalizm özellikle teknolojinin sunduğu imkânları kullanarak düşük maliyetli ve verimli üretim gerçekleştirerek tüketim toplumuna giden yolda önemli bir toplumsal dönüşüm gerçekleştirmiştir (Matsuyama, 2002). Sonraki süreçte kapitalizm, endüstriyel üretim yapılarak kâr elde edilmeye çalısıllan bu dönemin ardından paranın hareketi ve risk yönetimi üzerinden daha verimli ve düşük maliyetli kâr elde etmenin imkânlarının ortaya çıktığı finansal kapitalizme doğru evirilmiştir (Lapavitsas, 2014). Bu dönüşümün en önemli sebebi, birikmiş sermayeyi reel üretim yapmak için kullanmak yerine finansal araçlara yatırım yaparak değerlendirmenin daha fazla kâr getirmesidir (Orhangazi, 2008). Burada altı çizilmesi gereken bir husus, her ne kadar kâr elde etme yolları değişse de kapitalist sistemin temelinde bulunan sermaye birikimi ve sınırsız kâr arzusu değişmemekte, sadece -piyasa sisteminin mantığına uygun olarak- daha verimli ve daha düşük maliyetli yatırım imkanları üzerinden kâr elde etme amacı gerçekleşmektedir.

Zikredilen bu dönüşümler neticesinde, kapitalist piyasa sisteminin bir parçası olan finans sektörü günümüzde giderek daha fazla ağılık kazanarak küresel ticarette daha fazla yer edinmeye başlamışırır (Fimbel, Binninger, \& Karyotis, 2015). Diğer bir ifadeyle, endüstriyel devrim ile beraber toplumdaki ilişki ve kurumları şekillendirmeye başlayan ekonomi de artık finans sisteminin prensiplerine göre 
belirlenmektedir. Günümüz ekonomisini tanımlamak için kullanılan finansal kapitalizm bazı yazarlar tarafından toplumlardaki ekonomik eşitsizlik ve adaletsizliğin temel kaynaklarından biri olarak gösterilse de (Shiller, 2012; Tridico, 2017), Shiller (2012) gibi yazarlar sorunun daha ziyade finansal kapitalizmdeki yapısal eksikliklerden kaynaklandığını ve arıî olan bu problemlerin giderilmesi neticesinde iyi toplum (good society) oluşturmak için finansal kapitalizmin önemli olduğunu zikretmektedir.

İslam ekonomisinin temel ilkeleri açısından ekonomik sistem değerlendirildiğinde, toplumsal dayanışmanın var olduğu (lqbal Z. \& Mirakhor, 2013), insanların refahının (human well-being) temin edildiği (Asutay, 2007), faize dayalı finansal araçlarla borçlandırma yerine kâr-zarar ortaklığının tercih edildiği (Chapra, 2006; lqbal, M. M., 2010) ve adaletli ve hakkaniyete dayalı bir finansal sistemin öngörüldüğü (Siddiqi, 2004) anlaşılmaktadır. Ancak modern dönemde gerçekleşen dönüşümler dikkate alındığında, bu temel ilkelerin gerçekleşmesinin önüne geçecek kırılmaların yaşandığı görülmektedir. Bunların en başında, modern toplumu oluşturan üyelerin topluma bir birey olarak dahil olması ve modern öncesi dayanışmanın -ülkeler arasında farklılık görülmekle beraber- büyük ölçüde yitirilmesi neticesinde, toplumsal dayanışma aracılığıyla giderilen ihtiyaçlar ile yerine getirilen eylemlerin artık refah devleti kurumları ve piyasa tarafından gerçekleştirilmesi gelmektedir. Hem piyasanın hakimiyetini kolaylaştıran hem finansal sistemin reel ekonomiye faydasını azaltan hem de toplumsal eşitsizliğin ortaya çıkmasına sebep olan diğer bir gelişme ise tüzel kişiliğin varlık bulması olmuştur. Öyle ki, bireyselleşen toplumlara rağmen bireyler arası dayanışma hâlâ varlığını sürdürürken, tüzel kişiliklere sahip kâr amacı güden ticari şirketler sınırsız kâr elde etme arzusuyla finansal kapitalizmin giderek büyümesine yol açarak hem maddi eşitsizliğin artmasına hem de borca dayalı finansal araçların sistem içerisinde ağırlık kazanmasına yol açmaktadır.

Bu çalışmanın amacı, tüzel kişilik kurumunun modern şirket yapılarının temelini oluşturması sebebiyle yapısal düzenlemelerin mevcut finansal kapitalizmi toplumun hizmetine sokacak bir hale getirmesinin imkânsız değilse dahi çok zor olduğunu göstermektir. Bunu yapabilmek için, ilk olarak cemaat halinde yaşayan topluluk üyelerinin birey olarak yer aldığı modern toplumlara geçişinin toplumun 
üyeleri arasındaki ilişkiyi nasıl etkilediğini ele alacağız. İkinci olarak, bireylerin kazanç elde etme yollarının tüzel kişilikler üzerinden gerçekleşmesinin toplumu oluşturan bireyler arasındaki ilişkiyi nasıl dönüştürdüğünü inceleyeceğiz. Üçüncü olarak, sınırsız kâr arzusu peşinde koşan tüzel kişiliğe sahip firmaların finansal ürünleri tercih etmesinin rasyonel bir sonuç olduğunu göstermeye çalışacağız. Son kısımda ise, bu argümanlar doğrultusunda İslam ekonomisi açısından tüzel kişiliğin ontolojik düzeyde problemli bir kurum olduğunu iddia edeceğiz.

\section{Bireyselleşmenin İki Temel Sebebi: Refah Devleti ve Kapitalist Piyasa Sistemi}

Aile bağlarının önemli olduğu, cemaatlerin dayanışma içinde yaşadığı modern öncesi dönemdeki insan (Durkheim, 2020; Emiroğlu \& Aydın, 2003; Fotopoulos, 1994), modern dönemde kendini ulus-devlet sınırları içerisinde bir vatandaş, kapitalist sistem içerisinde bir iş̧̧i ve toplum içerisinde bir birey olarak buldu. Bu dönüşüm neticesinde, elinde satacak emeğinden başka bir şey olmayan kalabalık bir grup modern öncesi sosyal ilişkiler ağından da büyük ölçüde soyutlanmış oldu. Bu soyutlanma ve neticesinde gerçekleşen bireyselleşmenin tezahürü farklı zaman dilimlerinde ve coğrafi bölgelerde değişiklik gösterse de ulus-devletin ve kapitalist piyasa sisteminin küresel bir olgu olmasından dolayı çoğu toplumları etkilediği iddia edilebilir.

Modern öncesi dönemde insanlar arasındaki ilişkileri tanımlayan ve en etkili kurumlardan biri olan din tarafindan belirlenen norm ve kurallar (Thornton \& Ocasio, 2008; Tönnies, 2019), aile kurumunun içerisinde yeni nesillere aktarılmakta ve içselleştirilmekteydi (Emiroğlu \& Aydın, 2003). Bunun neticesinde cemaat üyeleri arasında gönüllü bir dayanışma gerçekleşmekte (Durkheim, 2020) ve iktisadi faaliyetler gibi birçok davranış topluma gömülü olarak gerçekleşerek içinde yaşanılan cemaatin değerleri ve sosyal fayda göz önüne alınmaktaydı (Fotopoulos, 1994; Polanyi, 2010). Ancak modern toplumların oluşmasıyla beraber bu ilişkiler ağında önemli dönüşümler gerçekleşmiştir. Konumuzla ilgili olan en önemli gelişme, cemaatin bir üyesi olarak var olan modern öncesi insanların endüstriyel devrim ve kentleşme başta olmak üzere toplumsal alanda gerçekleşen 
dönüşümler sebebiyle modern toplumlarda bir birey olarak kendilerine yer bulmalarıdır (Bauman, 2000; Beck, 2011; Taylor, 2020). İnanç veya akrabalık bağları üzerinden birbirine bağlı olan ve ortak normlar üzerinden ilişkilerini şekillendiren modern öncesi cemaat üyeleri, akıl ve çıkar merkezli hareket eden bireylere dönüşerek modern toplum içerisindeki işbölümüne dahil olmak suretiyle toplumsal ilişkilerini kurar hale gelmiştir (Durkheim, 2020). Modern toplumda bir birey olarak var olmanın en önemli yolu ise bu işbölümünün bir parçası olarak meslek edinmek ve çalışmaktan geçmektedir (Gorz, 2007; Méda, 2012).

Bireyselleşmenin ve toplumda işbölümü üzerinden yer edinebilmenin önemli bir sonucu, modern öncesinde gerçek kişilikler üzerinden kurulan organik ve küçük çaptaki ilişkilerin tüzel kurumlar üzerinden anonim kimlikler aracılığıyla kurulan ve ulus-devletin kurumları veya piyasa sistemi üzerinden şekillenen organik olmayan ilişkilere dönüşmesidir (Sencal \& Asutay, 2019; Van Der Loo \& Van Reijen, 2014). Bu tüzel kurumlardan bazıları modern öncesi dönemde cemaat yaşamı ve dayanışma sayesinde temin edilebilen imkânları piyasa sistemi üzerinden bireylere bir meta olarak sunarken, okul gibi bazı kurumlar ise modern öncesi dönemde aile başta olmak üzere cemaat üyeleri aracılığıyla gerçekleştirilen ve yeni üyelere aktarılan değer, bilgi ve becerileri, ulus-devletin ve kapitalist piyasa sisteminin kurumsal mantıklarına uygun şekilde yeni üyeleri eğiterek toplumun bir parçası kılmayı amaçlamaktadır. Ulus-devlet ve kapitalist piyasa sistemi bu bağlamda birbirini tamamlayan ve modern toplumun temelini oluşturan iki sistemdir (Giddens, 2013).

Bireyselleşmenin günümüz modern toplumunda gittikçe artmasının arkasında iki temel itici güç bulunmaktadır: (1) Ulus-devletin bir türü olarak refah devleti modeli ve (2) kapitalist piyasa sistemi. Refah devletleri vatandaşlar için bir güvenlik ve destek ağı oluşturarak vatandaşların ihtiyaç duyduğu desteği toplumsal ilişkilerden ziyade merkezi otoriteden sağlamaktadır. Bu durum da toplumsal dayanışma mekanizmalarını zayıflatmakta ve vatandaşları refah devletinin sunduğu imkânlara muhtaç halde bırakmaktadır (Kosotieti, 1987). Günümüzde mevcut olan ulus-devletlerin her biri belli bir dereceye kadar refah devleti modelini uygulayarak belli hizmetleri vatandaşlara sunmakta ve gerekli durumlarda maddi 
destek vermektedir (Gilbert \& Terrell, 2002). Bu hizmetlerin başında aynı zamanda devletin ideolojik bir aygıtı olarak faaliyet gösteren okullar (Althusser, 2014) aracılı̆ıı ile sunulan ücretsiz eğitim gelirken, kapitalist sistem içerisinde işçi olarak yer almış kişilere zor duruma düştüklerinde devlet tarafından sunulan işsizlik ve emekli maaşı gibi yardımlar da bahsi geçen hizmetlerin önemli bir kısmını oluşturmaktadır. Dolayısıyla, bu tür ihtiyaçların devlet tarafından sağlanıyor olması insanların sorumluluklarını devlet kurumlarına havale ederek sivil toplumun daha pasif şekilde faaliyet göstermesine yol açmaktadır (Kosotieti, 1987).

Bireyselleşmenin artmasında etkili diğer bir faktör ise kapitalist piyasa sistemidir. Modern öncesi cemaatlerde ücretsiz ve dayanışmanın bir parçası olarak sağlanan eylemler modern toplumda bir meta olarak piyasada satılmaktadır. Bu metalar yardımlaşma ve imece usulü gibi fiziksel desteklerin emek gücü olarak piyasada satılması olabileceği gibi (Polanyi, 2010), ihtiyaç duyulduğunda sağlanan karz-ı hasen'in (iyi borç) yerini alan faiz karşııı̆ı̆ borç da olabilir. Borç ile ilgili olarak vurgulanması gereken bir nokta, modern öncesi dönemde de mevcut olan faiz karşılığı borç alabilme imkânının günümüz kapitalist piyasa sisteminde en temel meta olarak finansal piyasaların merkezinde yer almasıdır. Örneğin, modern öncesi Müslüman toplumlarda faiz ile borç alma görülürken, insanlar maddi ihtiyaçlarının çoğunluğu dayanışma içerisinde akrabalık ve komşuluk bağları sayesinde giderilebilmekte (Lapidus, 1990) veya faiz geliri üzerinden kâr amacı gütmekten ziyade insanların kısa süreli nakit ihtiyacını karşılamak üzere kurulan para vakıflarına başvurabilmektedir (Bulut \& Korkut, 2019). Günümüzde ise bu tür ihtiyaçlar banka kurumu başta olmak üzere toplanan mevduatların faiz geliri elde ederek kâr elde etmeyi amaçlayan finansal kurumlar aracılığı ile çözülmesi istenmektedir.

Modern öncesi dönemde İslam dininin hedeflediği cemaat hayatının bir yansıması olarak yardımlaşma ve dayanışma, ilişkileri belirleme ve şekillendirme noktasında önemli bir rol oynarken dünyanın farklı bölgelerinde ulus-devlet çatısı altında bu ilişkiler hâlâ varlığını sürdürmektedir. Ancak kapitalist piyasa sisteminin toplumları piyasa mantığı üzerinden şekillendirme gayreti de aynı şekilde devam etmektedir. Özellikle İslami finans kurumlarının bu piyasa sisteminin bir parçası olması ve borca dayalı olarak büyümeleri (Asutay, 2012), Müslüman toplumlarda 
da birçok ürün ve hizmetin metalaşmasına yol açmaktadır. Bu noktada özellikle Müslüman toplumlarda başta ulema olmak üzere farklı paydaşlarca İslami normatif yapıyı koruma gayretleri Polanyi'nin karşı hareket (counter-movement) diye kavramsallaştırdığı yapıyı andırmaktadır (Polanyi, 2010). Diğer bir ifadeyle, finansal kurumlar gibi kapitalist piyasa sisteminin kurumları toplumlardaki organik ilişkileri kopararak piyasa sisteminin sunduğu ürün ve hizmetler aracılığıyla organik ilişkilerin ortadan kalkmasıyla oluşan ihtiyacı gidermeye çalışmaktadır. Bazen de finansal kurumların çıkardığı ürün ve hizmetler bu organik bağları tehdit etmektedir. Bu durumun somut bir örneğini Sudan'daki İslami finans kurumlarının borca dayalı hizmetlerin yelpazesini arttırmak için yaptıkları girişimin merkezi fetva kurulu tarafından toplumdaki dayanışma ve yardımlaşma ruhunun muhafazası amacıyla reddetmesi oluşturmaktadır. Bu durumu daha detaylı açıklamak için Sudan'da verilmiş olan bu fetvayı incelemek yerinde olacaktır. ${ }^{1}$

Bahsi geçen fetvada, Sudan Merkez Bankası dahil bazı bankalar merkezi Şer'i danışma kuruluna tedavi hizmetinin bankalar tarafından finanse edilmesinin hükmünü sormaktadır. Araşsırmamız açısından bizi ilgilendiren heyetin ulaştığı "caiz değildir" hükmünden ziyade, bu hükmün sebebi olarak sunulan üç temel gerekçeden ilkidir:

Bu hizmeti yapamayacak durumda olan bir kişinin banka finansmanına başvurması, dayanışma, kardeşlik ve hısımlık ilkesinin yok edilmesi, kişiliğin zedelenmesi (öldürülmesi), hizmet arayan kişinin borçla tüketilmesi, yalnızlık duygusunun gelişmesi demektir. Öyle ki şeytanın vesveselerine ve etrafındakilerin düşmanlığına karşı savunmasız bırakır. Günümüzde aile ve komşularının dayanışma içinde olduğunu ve özellikle de ülkemizde bu görevi en iyi şekilde yerine getirdiğini unutmamak gerekir. Bankalar bu hizmetin finansmanına her girdiklerinde; insanlar, kendilerinden daha büyük imkanlara sahip kurumların bu görevi yerine getirdiğini düşünerek dayanışmadan ellerini çekmişlerdir.2

\footnotetext{
1 Fetvanın Arapça orijinalini makalenin sonunda ek olarak bulabilirsiniz. Bu kısımda sadece ilgili kısmın tercümesi yer alacaktır.

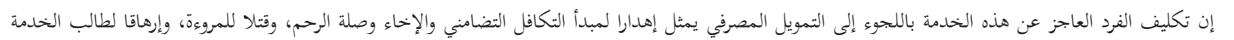

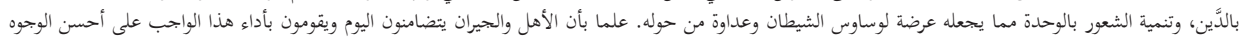

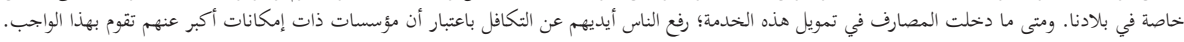


Hükmün ilk gerekçesinde de belirtildiği üzere kapitalist sistemin en önemli kurumlarından olan (İslami) bankanın bu tarz bir hizmet sunması akrabalar, komşular ve genel olarak toplum içerisinde bulunan dayanışma ve yardımlaşma ilişkilerini yıkma tehlikesi barındırmaktadır. Heyeti oluşturan alimlerin sözleşmenin şekilsel uygunluğunun ötesine giderek bu tür bir ürünün nasıl bir toplumsal dönüşüme yol açacağını öngörmesi ve fetvasını bu sonuçların İslam'ın maksatlarıyla ne derece uyumlu olduğunun değerlendirilmesi üzerine kurması kapitalist hegemonya karşısında toplumsal dinamiklerin farkında ve İslam'ın maksatlarını kapitalist sistemin maksatlarından ayırt edebilecek yetkinlikte alimlerin karşı-hareket yapabilmeleri için ne derece önemli olduğunu da ortaya koymaktadır.

Görüldüğü üzere, modern toplumu oluşturan bireylerin arasındaki dayanışma ve bağlar farklı toplumlarda farklı derecelerde bulunmaktadır. Ancak refah devletinin vatandaşlara dayanışma ve yardımlaşmanın yerini alan imkânlar sunması ve kapitalist piyasa sisteminin dayanışma ve yardımlaşmayı metalaştırarak piyasada sunulan ürün ve hizmetler aracılığıyla gerçekleştirmesi modern toplum içerisinde yaşayan insanların giderek bireyselleşmesine ve bunun tüm toplumları kapsayacak şekilde genişlemesine yol açmaktadır. Bu noktada bireyselleşen modern toplumda dahi iyi toplum (good society) dinamiklerinin bulunabileceğinin ümidini veren iki husus kendini göstermektedir. Bunlardan ilki yetkin alimlerin farkındalığı ve karşı-hareket sergileyerek kapitalist sistemin toplumun piyasalaşmasına engel olma çabalarıyken diğeri gelenek ve kültürden gelen dayanışma ve yardımlaşmanın hâlâ modern toplumlarda -belli bir seviyede- etkin olmasıdır. Ancak bu iyimserlik, üretim-tüketim sürecinin kapitalist üretim mantığının temelini oluşturan sınırsız kar arzusunun tüzel kişilik kurumu ile birleşmesi sebebiyle azalmaktadır. Bunun yanı sıra toplumsal ilişkiler de bireyler yerine tüzel kişilikler üzerinden kurularak, bireylerin gelenek ve inançları sebebiyle -bireyselleşmiş olsalar dahi- yapacakları yardım ve dayanışma faaliyetlerinin yine kapitalist piyasa mantığı üzerinden şekillenmesine yol açmaktadır (Sencal \& Asutay, 2019). Sonraki bölümde, tüzel kişilikler üzerinden üretim ve yardımlaşma faaliyetlerinin yapılıyor olmasının nasıl sonuçlar doğurabileceği üzerine incelemelerde bulunacağız. 


\section{Tüzel Kişiliğin Toplumsal İlişkilere Etkisi}

Modern öncesi Müslüman cemaatlere baktığımızda, Müslümanların ticaret, ziraat veya zanaat gibi uğraşlar sayesinde kazanç elde ettiklerini görürüz (Orman, 2015). Her ne kadar Çizakça (2011, s. 17) gibi araştırmacılar "sınırsız kâr elde etme" (endless profit) arzusunun -günümüzdeki gibi materyal bir arzudan ziyade yardımlaşmayı ön plana alan bir açıdan olsa dahi- İslam'ın ortaya çıktığı dönemde ve sonraki dönemlerde yaşamış Müslümanlar tüccarlarda olduğunu iddia etse de dinin belirlediği bir ilişkiler ve kurumlar ağı içerisinde (Thornton \& Ocasio, 2008) Müslümanların sınırsız karkâr arzusuna sahip olmaktan ziyade dinin belirlediği şekilde Allah'a kulluk yapabilmek için kazanç elde etme uğraşlarını bir vesile olarak gördükleri -İmam Muhammed'in Kitab'ul Kesb metni başta olmak üzere- klasik İslami kaynaklara dayanarak iddia edilebilir (Orman, 2015).

Kazanç elde etmeye dair bu bakış açısı özellikle insanların gerçek kişiler olarak birbirleriyle ilişki içerisinde oldukları, birbirlerini tanıdıkları ve ilişkilerinin sadece iktisadi ilişkiler ile sınırlı olmadığı bir cemaat yapısında daha anlamlı olmaktadır. Çünkü modern dönemdeki gibi kapitalist piyasa sisteminin toplumu kendisine gömülü hale getirerek toplumdaki hâkim olan prensipleri belirlediği ve ilişkileri ve kurumları bu prensipler bağlamında yeniden şekillendirdiği bir yapıda bireylerin sınırsız bir kâr arzusuna sahip olmaları normal görülebilir. Ancak önceki bölümde açıkladığımız üzere bireyler kendileri olarak toplumun içerisinde bulundukları sürece, sınırsız bir kâr arzusu ile hareket ettiklerini varsaysak dahi, içinde bulundukları kültür, inanç ve gelenekten gelen şekillendirmelerin hâlâ etkili olacağı ve bireylerin gördükleri, tanıdıkları veya akrabalık ilişkisi içerisinde oldukları insanlara karşı yardımlaşma isteği duyacağı iddia edilebilir.

Modern toplumdaki insanların bireysel olarak iktisadi faaliyetlerini gerçekleştirmek yerine tüzel kişiliklere sahip şirketler (corporate) üzerinden kazanç arayışında bulunmaları ve aynı zamanda Müslüman toplumlardaki zekât ve sadaka gibi birçok yardımlaşma aracının bireysel olarak yerine getirilmesi yerine tüzel kişiliklere sahip dernek ve vakıflar üzerinden gerçekleştirilmesi tüzel kişiliğin toplumsal ilişkileri önemli ölçüde değiştirmesine yol açmaktadır. Bu dönüşümlere geçmeden önce tüzel kişiliğin ortaya çıkışını ve İslam hukuku açısından meşruluğunun gerekçelerini eleştirel bir açıdan ele almamız uygun olacaktır. 
Günümüzde varlığı ve hukukiliği bir tartışma konusu olmaktan çıkmış olan tüzel kişilik kavramının kökenleri eski hukuk sistemlerine kadar götürülse de (Okandan, 1951) modern anlamıyla tüzel kişilik kurumunun ortaya çıkması 19. yy da gerçekleşmiştir (Öztan, 1994). Kuran (2011, ss. 59-61) gibi bazı araştırmacılar tüzel kişiliğin İslam hukukunda olmaması sebebiyle ortaklığa üye olan kişilerin davranışlarından bireysel olarak sorumlu olacaklarını ve bunun da ortakların almayı göze alacakları riski azaltacağını ifade ederek ortaklıkları sınıladığını iddia etmektedir. Hallaq (2013, ss. 153-154) ise Şeriat'ın ahlaki yapısının bireysel olarak insanların hesap vermeleri üzerine dayalı bir hukuk sisteminin varlı̆̆ından dolayı modern anlamdaki tüzel kişiliğe izin vermeyeceğini iddia ederek, Müslümanların tüzel kişiliği bulamaması değil İslam dini tarafından şekillenen ahlaki toplumun içerisinde böyle bir kurumun ticari amaçlarla ortaya çıkmasının imkânsızlığını vurgulamaktadır.

Son on yıldaki yaygın olan görüş tüzel kişiliğe sahip şirketlerin İslam hukuku açısından caiz olduğu yönündedir (Zahid, 2013). Bu hükmün delillendirilmesinin altında modern ticari şirketlerin sahip olduğu tüzel kişiliğin devlet, beytü'l mal, mescit ve vakıf gibi tüzel varlıklara kıyas edilmesi yatmaktadır (Köse, 1998; Zahid, 2013; Zahraa, 1995). Ticari şirketlerin tüzel kişiliğe sahip olabileceği yönündeki bu meşrulaşırırma çabalarının arka planında iki temel gerekçe bulunabilir. Bunlardan biri Kuran'ın (2011) belirttiği gibi Müslüman toplumların -ekonomik-geri kalmışlı̆̆ını sebebi olarak tüzel kişilik kurumunun eksikliği iddiası kabul edilerek bu yönde bir telafi girişimidir. Tüzel kişilik kurumu sayesinde Müslüman toplumlarda sermaye birikimi sağlanacak ve neticede ekonomik kalkınma gerçekleşecektir. Eğer bu yönde bir çaba varsa, burada ulema -farkında olarak veya olmayarak- kapitalist piyasa sisteminin sahip olduğu bir varsayımı kabul etmiş anlamına gelmektedir: -İslam ahlakından taviz verilmesi gerekse dahi- ekonomik kalkınma sağlanmalıdır ve bunun tek yolu sermaye birikimini sağlayacak tüzel kişilik kurumunun caiz görülmesidir. İkinci ihtimal ise toplumdaki ticari girişimlerin gerek ulus-devletin sunduğu vergi avantajlarından istifade etmek için gerekse de sonuçlarını düşünmedikleri için ticari faaliyetlerini tüzel kişilikler aracılığı ile yapmaları ve İslam hukukçularının bu yaygınlaşmış kurumu meşrulaştırma girişiminde olmalarıdır. Görüldüğü üzere bu iki gerekçe de tüzel kişiliğin Müslüman toplumların dışından empoze edildiği ve bir şekilde İslam hukukunda yer edinme 
gayretinde olduğu varsayımındadır. Üçüncü bir ihtimal olarak ulemanın kendi kanaatiyle ticari kurumların tüzel kişiliklere sahip olmalarını meşru olarak görmesi 14. yüzyıl boyunca ortaya çıkmamış bir yapının neden Batı'da ortaya çıktıktan sonra sömürge sonrası dönemde meşru kılındığı sorusunu akla getirebilir.

Burada önemli bir husus, tüzel kişiliği meşru kılmak için kıyas edilen kurumların her birinin ibadet veya Müslümanların felahı için kurulmuş olan kurumlar olmasıdır. Bu sebeple tartışmalı olan konu tüzel kişiliğin İslam hukukunda varlığından ziyade, sınırsız kâr elde etme arzusuyla kurulan ve sermaye birikimini sağlamak ve şirket sahiplerinin üzerindeki riski azaltmak için ortaya çıkan ticari şirketlerin tüzel kişiliğinin İslam hukuku açısından durumudur. Hâlbuki kıyas daha ziyade tüzel kişiliğin mevcudiyeti üzerine inşa edilmektedir. Bu bölümün kalan kısmında ticari tüzel kişiliklerin varlığının niçin İslam ahlakı ile uyuşmadığını ve toplumsal ilişkilerin nasıl bir dönüşüme uğradığını ele alacağız. Sonraki bölümde ise bunun bir uzantısı olarak tüzel kişiliğin finansallaşma ile ilgisine değineceğiz.

Ticari bir tüzel kişiliğin temel amacı şirket hissedarlarının karlarını maksimize etmektir (Jensen, 2010). Hissedar teorisi olarak kurumsal yönetişim literatüründe yer edinen ve geleneksel şirketleri tanımlayan bu amaç, hissedarları oluşturan genel bir kitlenin ortak amacı olarak görülmektedir. Genel varsayım insanların sınırsız kâr arzulaması olduğu için, tüzel kişiliklerin insanların ortak amacına göre bir hedef belirlemesi normal görülmektedir. Friedman'ın (2007) iddia ettiği üzere, bir şirketin tek sosyal sorumluluğu hissedarlarının kârını maksimize etmektir. Eğer hissedarlardan bazıları kişisel, dini veya kültürel sebeplerle yardımda bulunmak isterse bu onun kişisel tercihi olacaktır ve şirketten elde ettiği geliri istediği şekilde tasarruf edebilecektir. Ancak tüzel bir kişiliği olan şirket -kâr payı olarak dağıttığı kısım hariç- gelirlerini yeniden yatırıma dönüştürmeli ve kapitalist sistemin en önemli prensiplerinden olan sürekli büyümeyi hedeflemelidir.

Bu durumda son on yıllarda literatürde yer bulmaya başlayan kurumsal sosyal sorumluluk çerçevesinde tüzel kişiliğe sahip şirketlerin kâr amacı gütmeden yaptığı, toplumun bir parçası olarak topluma geri vermeye dayalı yardımları nasıl değerlendirebiliriz? Bu soruya üç cevap vermek mümkündür. Birincisi, bu şirketlerin 
kurumsal yönetişime kıta Avrupası tarzı bir yaklaşım sergilemeleri ve sadece hissedarların kârının maksimize edilmeye çalışılması yerine bütün paydaşlara önem verilmesini temsil eden paydaş teorisini (stakeholder theory) benimsemeleridir (Freeman, 1984). íkinci bir cevap, bu şirketlerin yaptıkları hesaplamalar neticesinde doğrudan şirkete kâr getirmeyecek olan bu yatırımlar aracılı̆ı ile şirketin reklamının yapılması, siyasi veya kurumsal ilişkilerin kurulması gibi dolaylı katkıları sebebiyle uzun vadede masraflarını çıkartacağı ve aynı zamanda toplum gözünde şirkete ait iyi bir imaj bırakacak olması dolayısıyla kurumsal sosyal sorumluluk bağlamında hareket etmesidir (Mackey, Mackey, \& Barney, 2007). Üçüncü bir cevap ise devlet düzenlemeleri, sektörel bazda alınan kararlar ve bağımsız kuruluşların denetlemeleri gibi kurumsal düzeyde etkenler sebebiyle sosyal sorumluluk projelerine dahil olmalarıdır (Campbell, 2007). Dışarıdan bakan bir değerlendirme ile bir şirketin sosyal sorumluluk bağlamında yaptığı girişimlere bu pozisyonlardan hangisinin yol açtığını bilmek zordur. Ancak kapitalist piyasa sisteminin kurumsal mantığını ve şirketleşmenin arkasında yatan motivasyonu düşündüğümüzde, tüzel kişiliğe sahip şirketlerin çoğunluğunun şirket değerini artırmak ve hissedarlarına azami seviyede kâr dağıtmak olduğunu iddia edebiliriz. Topluma geri vermek düşüncesiyle sosyal sorumluluk projeleri yapan şirketlerin dahi neticede ticari bir oluşum olarak amacı kâr maksimizasyonu olmaktadır.

Şu ana kadar yapılan tartışma bize göstermektedir ki ortaya çıkış ve var oluş amacı itibariyle tüzel kişiliğe sahip şirketler modern öncesi dönemdeki gibi din başta olmak üzere toplumu şekillendiren ana kurumsal mantıklar tarafından belirlenen cemaat üyeleri arasındaki gerçek ilişkiden bağımsız olarak, kapitalist piyasa sisteminin mantığı tarafından belirlenen ve sınırsız bir kâr amacı peşinde koşan tüzel varlıklardır. Bu sebeple, ahiret inancına sahip ve hesap verme bilinciyle hareket eden bir Müslümanın davranışlarını şekillendirecek İslam ahlakı şirketler için geçerli olmayacaktır. MÜSIAD (Müstakil Sanayici ve Işsadamları Derneği) üyelerinden Murat Ülker'in de belirttiği üzere, "...[t]üzel kişilikler işlerini yaparken laik, seküler vs. olmaz; böyle kimlikler doğru değil, herkes kendi işini yapar, yapmalı" (Babacan, 2018, ss. 243-244).

Burada bir ayırım yapmak gerekebilir. Piyasanın kurallarına göre hareket eden ve şirket hedeflerini ve kararlarını piyasa mantığına göre belirleyen şirketler küçük 
şirketlerden ziyade belli bir büyüklüğe ulaşmış olan ve küresel piyasalarda rekabete girmiş orta ve büyük ölçekteki şirketlerdir. Bunun sebebi, Mustafa Özel'in de vurguladığı gibi, "[b]elli bir kritik kütleye kadar insan sermayesinin hakimidir; ama o ölçeğe ulaşınca şirket ve sermayenin kuralları hakim olmaya başlar... iş̧̧iye istediğin ücreti vermen de zorlaşmaya başlar, hatta taşeron sistemine geçmek zorunda dahi kalabilirsin..." (Babacan, 2018, ss. 244-245).

Tüzel kişiliğe sahip -özellikle orta ve büyük ölçekteki- şirketler sürekli büyüyerek daha fazla kar peşinde koşarken elindeki kaynakları en verimli ve düşük maliyetli olacak şekilde kullanmaya çalışır. Bu kaynakların başında beşeri sermaye ve doğa gelmektedir. Polanyi'nin belirttiği üzere, bu iki metanın piyasada sürekli hazır olması kapitalist sistemin devamı için şart olan bir durumdur (Polanyi, 2010). Bu sayede endüstriyel devrim sonrasında teknolojinin kullanılarak insanları ve doğayı piyasa sisteminin kurallarına göre çerçevelemesi sağlanmakta ve üretimin ve kârın devamlılığı garanti altına alınmaya çalışılmaktadır (Etil, 2014). Bu üretim sürecinin temelinde sınırsız üretimden ziyade sınırsız kâr arzusu yattığı için daha verimli ve düşük maliyetli kâr elde etme yolları oluştuğunda -toplumun zararına yol açsa dahi- tüzel şirketler ve bu şirketlerin yöneticilerinin bu yollara yönelmeleri beklenir. En azından rasyonel bir şirketin davranışı bu şekilde olmalıdır. Bu sebeple, finansal ürünler aracılığı ile üretim yapmadan sadece para hareketliliği ve risk yönetimi yaparak reel üretimden daha fazla kâr elde imkânının oluşturulması finansal kapitalizmin yükselişine yol açmaktadır. Sonraki bölümde tüzel kişilik üzerine kurulu bu yapının finansallaşmanın artmasındaki rolünden bahsedip ardından İslam ekonomisi açısından bir değerlendirmesini sunacağız.

\section{Tüzel Kişiliğin Finansallaşmaya Etkisi}

Önceki bölümlerde yaptığımız değerlendirmeler göstermektedir ki tüzel kişilik kurumu modern toplumdaki bireylerin ortak hedefi olarak gördügü kâr arzusunu şirketin ilk amacı olarak belirlemiştir. Bunun yanı sıra tüzel kişilikler üzerinden ticaret yapan şirketlerin hukuki olarak sahip olduğu sınırlı sorumluluk yöneticilerin modern öncesinde yaygın olan şahıs ortaklıklarına nispeten daha fazla risk almasına imkân tanımaktadır. Çoğunlukla gelir risk karşılığında olduğu için, bazı yöneticiler 
kaybedildiği durumda çok fazla zarar edilmeyeceği ve sermaye sağlayan ortakların risklerinin sadece yapmış oldukları yatırım ile sınırlı kalacağı ancak kazanıldığı takdirde yüksek gelirler elde edileceği yatırım yollarını tercih edebilmektedir. Özellikle 2008 küresel finansal krizi göstermektedir ki birçok şirket finansal araçlara yatırım yaparak şirketlerin kârlılığını artırmaya gayret etmişlerdir.

Modern öncesi dönemde yaygın olduğu üzere şahısların bir araya gelip kısa vadeli veya uzun vadeli ortaklıklar kurarak ticaret yaptığı durumlarda, borçların yükümlülüğü bizzat ortaklar tarafından üstlenildiği için ortakların yüksek riskli veya borca dayalı girişimlerde bulunmaları modern dönemle mukayese edilince daha az beklenmektedir. Halbuki modern şirketlerde büyüme için yapılacak yatırımların kaldıraç (leverage) kullanılarak borca dayalı finanse edildiği görülmektedir (Acharya, Franks, \& Servaes, 2007). Bu sayede daha yüksek hacimli yatırımlar yapılarak kâr aynı ölçüde artırılabilmektedir. Bu yatırımlar endüstriyel devrimin başından itibaren gerçekleştiği üzere reel üretimi finanse etmek için kullanılabileceği üzere, 2008 finansal krizde şahit olunduğu üzere yüksek kazanç ümidi sağlayan finansal ürünlere yatırım için de kullanılabilmektedir.

Modern toplumda yaşayan insanlar bireyselleşmiş olsa dahi yüksek riskli yatırımlar yapacak kişi sayısı risk-alıcı diye tabir edilen belli bir grup ile sınırlı olması ve bireyler arasındaki ilişkilerin -modern öncesi dönemdeki kadar olmasa dahibelli bir yardımlaşma ve dayanışmayı içermesi beklenirken, tüzel kişilik sahibi şirketler sayesinde ticari faaliyetlerde -sınırsız- kâr elde etme arzusu temelde olmakta ve hangi yol daha verimli ve düşük maliyetli şekilde kâr elde etme imkânı tanıyorsa şirketlerin karar mekanizmasının o tarafı tercih etmesi beklenmektedir. Bu bağlamda finansal ürünler bu talebi en iyi şekilde sağlayabiliyorken, sahip oldukları risk tüzel kişiliklerin sınırlı sorumluluk sahibi olmaları sayesinde -gelmesi beklenen kâr göz önüne alındığında- göze alınabilir gelmektedir. Diğer bir ifadeyle, ticaret ile uğraşan kişilerin bireysel sorumluluk aldığı durumlarda üstlenilmeyecek riskler, sınırlı sorumluluk sayesinde üstlenilebilmektedir. Alınan bu riskler de toplumun refahı ve faydasından ziyade, şirketlerin daha fazla kâr elde etmesi için yapılmaktadır. Hatta 2008 finansal krizi başta olmak üzere finansal krizlerin birçoğunun şirketlerin bu açgözlülüğünün sonucu olarak ortaya çıktığı ve 
toplumsal düzeyde yıkıcı etkilere yol açtığı iddia edilebilir (Boddy, 2011; V. Lewis, Kay, Kelso, \& Larson, 2010).

Çoğunlukla sıfır-toplamlı bir oyun olarak işleyen türev ürünler başta olmak üzere finansal ürünlere yatırım yapan firmalar reel ekonomiden elde edebilecekleri kârdan daha fazlasını elde etmeye amaçlamaktadır. Bunun neticesinde ise finansallaşma hızlanarak gelişmekte ve toplumdaki gelir dağılımı eşitsizliği artmaktadır (Dore, 2008; Dünhaupt, 2014; Van Arnum \& Naples, 2013). Bunun yanı sıra, düzenlemelerdeki eksikliklerden ve hukuki boşluklardan yararlanan birçok yatırımcı kısa vadede yüksek kârlar elde etmek için finansal piyasaların krize sürüklenmesi pahasına spekülasyon veya riskli yatırımlar yapmaktadırlar (Brunzell, Hansson, \& Liljeblom, 2011). Bu tür davranışlar özellikle batmasına izin verilmeyecek kadar büyük (too big to fail) şirketler için daha geçerlidir. Çünkü bu şirketlerin yöneticileri yüksek primler kazanarak altına girdikleri risklerin karşılığını maddi olarak elde ederken, riskin gerçekleşmesi ve zararın ortaya çıkması durumunda -tarihi tecrübeden yola çıkarak- devletlerin bu şirketleri kurtaracağı güvenine sahiptirler (Ritholtz, 2009).

Tüzel kişilik sadece toplumsal ilişkileri etkileyerek anonim bir ilişki yapısını hâkim kılmakla sınırlı kalmamış, sahip olduğu sınırsız kâr elde etme amacı sebebiyle ve sınırlı sorumluluğu sayesinde ekonominin finansallaşmasında önemli bir rol oynamıştır. CDO (Collateralized Debt Obligation - Teminatlı Borç Yükümlülüğü) ürünlerinin ortaya çıkışı bunun önemli bir örneğidir. Daha fazla kâr elde etme arzusunda olan yatırımcıların ve şirketlerin ellerindeki sermayeyi yatırabilecekleri bir araç olan CDO'lar borçların meta olarak piyasada satılmasını sağlamış ve özellikle konut finansmanı (mortgage) için kullanıldığından dolayı ev piyasasının gereğinden fazla değerlenmesine yol açarak reel ekonomiye de zarar vermiştir. Neticede gerçekleşen küresel finansal kriz ve birçok kişinin işsiz kalması ise bu sürecin en önemli sonuçlarındandır. Ancak bu kriz tecrübesi kapitalist piyasa sistemi açısından yapısal bir değişikliğe yol açmamaktadır. Kindleberger'ın (2015) da belirttiği üzere, düzenleme ve denetlemeler sıkılaştırılsa dahi piyasadaki oyuncular hukuki boşluklardan faydalanarak yine en verimli ve düşük maliyetli kâr elde etme peşinde koşmaya devam edeceklerdir. 


\section{5. İslam Ekonomisi Açısından Bir Değerlendirme}

Bu çalışmanın iddiası İslami açıdan iyi bir toplumu temsil edecek ilişki ve kurumlar için ticari amaçla kurulan şirketlerin ontolojik olarak tüzel kişiliğe sahip olmasının İslam ahlakı ile çatıştığıdır. Murat Ülker'in de zikrettiği üzere, özellikle orta ve büyük ölçekli olan ve kapitalist piyasa sistemi içerisinde rekabete girmiş şirketler herhangi bir kimlikle anılmak yerine piyasa sistemi içerisinde üzerine düşen görevi yerine getirirler. Bu bağlamda tüzel kişiliklerin İslam ahlakı üzerinden faaliyet göstermeleri zor olacaktır; çünkü bu şirketler ve sahipleri ayrı kişiler olarak tahayyül edilmekte ve şirketlerin yönetim şekli içinde bulundukları piyasa tarafından şekillenmektedir. Diğer bir ifadeyle, bireysel hayatında İslami kurallara riayet etme hususunda çok dikkatli olan bir Müslüman tüzel bir şirketin ortağı olarak bu ahlaki yaşamın orada da hâkim olması için çaba gösterme ihtiyacı duymayabilir veya buna yetkisi olmayabilir. Çünkü şirketlerin sahip oldukları profesyonel yöneticiler şirketleri piyasanın şartlarına ve kurallarına uygun olarak yönetmektedir.

Bu bağlamda modern toplumun oluşmasıyla beraber artan bireyselleşme ile toplum üyelerinin arasındaki dayanışma ve yardımlaşma azalmış olsa dahi hâlâ varlığını sürdürürken, refah devletinin sunduğu imkânlar ve piyasa sisteminin meta olarak sattığı ürün ve hizmetler bu dayanışma ve yardımlaşmayı tüzel kişilikler üzerinden sunmaya başlamaktadır. Ayrıca birey olarak dahil olunan ticari faaliyetlerde gelenek, inanç ve kültürün etkisinin görülmesi beklenirken, piyasa kurallarına tabi olarak faaliyet gösteren -özellikle orta ve büyük ölçekteki- ticari tüzel kişiliklerin -kâr getirici bir etkisi olmadıktan sonra- bu tür etkilerden bağımsız şekilde rasyonel olarak kararlar alması beklenmektedir. Bunun da ötesinde, bu rasyonel tercihin bir uzantısı olarak, topluma zararlı olsa veya maddi eşitsizlikleri artırsa dahi reel üretim yerine daha verimli şekilde kâr maksimizasyonu sağlayacak finansal araçlara yatırım yapması beklenmektedir.

Son on yılda ortaya çıkan ve yatırımcı açısından İslam hukukuna uygun faaliyetler gösteren (satışı helal olmayan ürünlerin ticaretini yapan veya faiz ile iştigal eden finans kurumları gibi) şirketlerin bulunduğu endekslerin kurulması 
burada öne sürülen iddia ile çelişmemektedir. Çünkü İslam ahlakına dayalı olarak bir şirket yönetmek her ne kadar İslam hukukuna uygun ürün ve hizmetlerin ticaretini yapmayı kapsasa da bunun ötesine giderek bütün bir kurumun yönetişim sisteminin İslam ahlakına göre şekillenmesi anlamına gelmektedir ki bu şirket içerisinde yer alan paydaşlar arasındaki ilişki başta olmak üzere toplumun bir paydaş olarak görülmesi ve kâr elde etme uğraşı içerisinde yapılan her bir eylemin ve paydaşlara karşı sorumlulukların yerine getirilmesi hususlarında Allah'a hesap verme bilinciyle hareket etmek anlamına gelmektedir. Bu bağlamda İslami kurumsal yönetişim konusunda geniş bir literatür olsa da (Abu-Tapanjeh, 2009, s.; Ahmed \& Erkan, 2017; Choudhury \& Hoque, 2019; Hasan, 2009; Lewis, M. K. 2014) bu çalışmalar mevcut gerçeklik içerisinde İslami bir kurumsal yönetişim teorisi geliştirme çabası olduklarından dolayı tüzel kişiliği verili olarak kabul etmekte ve çalışmalar tüzel kişilik kurumunun varlığı üzerine kurulmaktadır.

Bu çalışmada işaret etmeye çalıştığımız husus İslam ahlakı üzerine kurulacak bir ekonomide ticari faaliyet gösterecek şirketlerin tüzel kişilik olarak var olmalarının problem edilmesi ve herhangi bir teorik tartışmaya girişmeden mevcut gerçekliği meşru kılmak için caiz görülen tüzel kişiliğin Müslüman toplumlarda nasıl bir dönüşüme yol açabileceğinin tartışılmasıdır. Tüzel kişiliğe sahip şirketlerin içsel bir özelliği olan sürekli sermaye birikimi ve büyüme ihtiyacl, modern Müslüman toplumlarda hâlâ mevcut olan yardımlaşma ve dayanışma ilişkilerini de piyasa sistemine dâhil ederek metalaştırma gayretini sürdürecektir. İslam ekonomisinin tesis edilebilmesi için en başta İslam ahlakının tesisi ve korunması yönünde bir çaba olarak toplumsal ilişkilerin organik (piyasa üzerinden kurulmayan) ve gerçek (tüzel kişilik üzerinden kurulmayan) olmaları için alimler ve düşünürler başta olmak üzere Müslüman bireyler -piyasaya karşı- bir karşı-hareket sergilemeli ve metalaşmayı ters çevirme (decommodification) ve İslam ahlakına dayalı ilişki ve kurumlar oluşturma yönünde çaba sarf etmelilerdir.

\section{Sonuç}

Modern toplumların bireyselleşmesi neticesinde toplumsal dayanışma ve yardımlaşma faaliyetlerinin metalaşarak tüzel kimlikler üzerinden piyasa 
mekanizması aracılığı ile gerçekleştirilmekte ve bu tüzel kişilik sahibi ticari şirketler kâr maksimizasyonu amaçlamaktadır. Bunun yanı sıra, bu şirketler sahip oldukları sınırlı sorumluluk sayesinde kâr elde etmek için riskli yatırımlara girebilmekte ve özellikle finansal piyasalar sayesinde kapitalist sistemin daha fazla finansallaşmasına yol açmakta, finansın topluma fayda sağlayacak üretim için bir araç olması gerekirken, şirketlerin doğrudan kâr elde etmesi için bir araç haline gelmektedir. Bu bağlamda tüzel kişiliğin ekonominin finansallaşması açısından önemli bir rolü vardır. Burada önemli olan husus, şirketlerin toplumdan bağımsız bir şekilde kâr amacı peşinde olmasının ve sınırlı sorumluluğa sahip olmalarının, bu şirketlerin faaliyetlerinin toplum açısından olumsuz neticelenecek davranışları sergilemelerinin de rasyonel bir hareket olacağı noktasıdır.

Hallaq'ın (2013) da vurguladığı üzere tüzel kişilik İslam ahlakı ile çatışma halindedir. Bu sebeple, Kuran'ın (2004) iddia ettiği gibi Müslüman toplumlar tüzel kişiliği bulamamış değil, Müslüman toplumları şekillendiren İslam ahlakı sebebiyle 'ticari amaçlı tüzel kişilikler' gibi bir olgunun ortaya çıkma ihtimali hiç olmamıştır. Bu çalışmada tüzel kişiliğin İslam ahlakı ile uyumsuz olma gerekçelerinden bazılarına değinerek, kapitalist piyasa sistemi içerisinde tüzel kişiliğe sahip şirketlerin finansallaşmayı arttırarak ekonominin finansal krizlere daha açık hale geleceğini ve ekonomik eşitsizliğin artacağını iddia ettik. Sermaye birikimi ve sürekli büyüme hedefine sahip olan tüzel şirketler, bunu başarabilmek için kapitalist piyasa sisteminin prensiplerine göre hareket etmek zorunda olduklarından dolayı İslam ahlakının gerektirdiği ilişki ve kurumların -şirket içerisinde- oluşturulmasından ziyade İslam hukukunun -faizden kaçınma, helal ürünlerin ticaretini yapma gibi- şekli şartlarını ve temel gereksinimlerini yerine getirme ile yetinmek zorunda kalacaktır. Mustafa Özel'in vurguladığı gibi, belli bir büyüklükten ve rekabet içine girdikten sonra kişisel tercihler ikinci planda kalmaktadır (Babacan, 2018, ss. 244-245).

Tüzel kişiliğin İslam ahlakı ile çatışma halinde olması günümüz kapitalist sistem içerisinde faaliyet gösteren ticari şirketler için ne anlama gelmektedir? Bu sorunun cevabı İslam ahlakı üzerine kurulu ticari ilişkiler ve ortaklıkların yapısı nasıl olmalı sorusuyla yakından ilişkilidir. Organik ilişkiler üzerine kurulu olan ve yaptıkları 
yatırımların sorumluluklarını alan ve hesabını hem dünyada hem de ahirette vereceği bilinciyle hareket eden şahısların bir araya gelerek kurdukları ortaklıklar İslam ekonomisi içerisinde yer alan ticari faaliyetlerin özünü oluşturmalıdır. Bu durumda Timur Kuran'ın (2011) belirttiği üzere ortakların ölümü ve sonrasında miras dağılımı sebebiyle ortaklıkların kısa vadeli olacağı ve uzun vadede sermaye birikiminin gerçekleşemeyeceği iddiası gündeme gelmektedir. Ancak bu gerçeğin Müslüman toplumlar açısından bir sorun olup olmadığı ayrı bir tartışmadır. Çünkü Kuran $(2004,2011)$ Batı gerçekliğini evrensel olarak olması gereken olarak sunarken, Hallaq'ın (2013, ss. 153-154) da belirttiği gibi, İslam ahlakı farklı kurumsal yapılar gerektirebilir. Bu durumda karşımıza İslam ahlakına uygun maddi ve manevi büyüme ve kalkınma olmalı mıdır? Olacaksa, nasıl gerçekleştirilebilir? Ve benzeri sorular çıkmaktadır. Bu soruların cevabı da İslam ekonomisinin temel kaynaklarına gidilerek araştırılmaya ihtiyaç duyulan yeni konulara işaret etmektedir. Bu çalışmanın kapsamı ise sermaye biriktirmenin evrensel bir gereklilik olduğu varsayımını temel alan ve bunun yolu olarak da tüzel kişilik kurumunun varlığını meşrulaştıran mevcut iktisadi sistemin İslam ahlakıyla uyumsuzluğunu tüzel kişilik kurumunun yol açacağı toplumsal sonuçlardan yola çıkarak göstermekti. Bu bağlamda, İslam'ın temel ilkeleri üzerine inşa edilmiş bir toplumda bireyselliği sürdürülebilir kılması ve bireyler arasındaki dayanışma ve yardımlaşmayı daha da azaltmasının yanı sıra, reel üretim yerine finansallaşmanın artmasına yol açacağı için tüzel kişiliğin İslam ahlakı ile uyumlu olmadığı iddia edilmektedir. Zira, İslam ahlakı, bireylerin ticari ilişkilerinde şahıs olarak yer almalarını öngörmektedir.

\footnotetext{
Teșekkür: Bireyselleşme bölümünü yazarken müracaat edilecek kaynaklar konusunda yardımcı olan Merve Soylu ve Merve Reyhan Ekinci'ye ve makalenin son okumasını yaparak geri bildirimde bulunan Esma Sağ Şencal'a teşekkür ederim.

Etik Komite Onayı: Çalışma etik kurul onayı gerektirmemektedir.

Hakem Değerlendirmesi: Dış bağımsız.

Çıkar Çatışması: Yazar çıkar çatışması bildirmemiştir.

Finansal Destek: Yazar bu çalışma için finansal destek almadığını beyan etmiştir.
}

Acknowledgement: I would like to thank Merve Soylu and Merve Reyhan Ekinci, who helped with the sources while writing the individualization section, and Esma Sağ Şencal, who provided feedbacks by making the proof reading of the article.

Ethics Committee Approval: The study does not require ethics committee approval.

Peer-review: Externally peer-reviewed.

Conflict of Interest: The author has no conflict of interest to declare.

Grant Support: The author declared that this study has received no financial support. 


\section{Kaynaklar/References}

Abu-Tapanjeh, A. M. (2009). Corporate Governance from the Islamic Perspective: A Comparative Analysis with OECD Principles. Critical Perspectives on accounting, 20(5), 556-567.

Acharya, V. V., Franks, J., \& Servaes, H. (2007). Private equity: Boom and bust? Journal of Applied Corporate Finance, 19(4), 44-53.

Ahmed, P., \& Erkan, M. K. (2017). Corporate Governance and Ethics of Islamic Finance Institutions. International Journal of Islamic Economics and Finance Studies, 3(1), 170-197.

Aliber, R. Z., \& Kindleberger, C. P. (2015). Manias, Panics and Crashes: A History of Financial Crises. New York, NY: Palgrave Macmillan.

Althusser, L. (2014). On the Reproduction of Capitalism: Ideology and Ideological State Apparatuses. London; New York: Verso.

Asutay, M. (2007). A Political Economy Approach to Islamic economics: Systemic Understanding for an Alternative Economic System. Kyoto Bulletin of Islamic Area Studies, 1(2), 3-18.

Asutay, M. (2012). Conceptualising and locating the social failure of Islamic finance: Aspirations of Islamic moral economy vs the realities of Islamic finance. Asian and African area studies, 11(2), 93-113.

Babacan, A. (2018). Piyasa Aklı ve Yeni Muhafazakar Ahlak. İstanbul: İz Yayıncılık.

Bauman, Z. (2000). The Individualized Society (1st edition). Cambridge, UK ; Malden, MA: Polity.

Beck, U. (2011). Risk Toplumu—Başka Bir Modernliğe Doğru. İstanbul: İthaki Yayınları.

Boddy, C. R. (2011). The Corporate Psychopaths Theory of the Global Financial Crisis. Journal of Business Ethics, 102(2), 255-259.

Brunzell, T., Hansson, M., \& Liljeblom, E. (2011). The Use of Derivatives in Nordic Firms. The European Journal of Finance, 17(5-6), 355-376.

Bulut, M., \& Korkut, C. (2019). Ottoman Cash Waqfs: An Alternative Financial System. Insight Turkey, 21(3), 91-112.

Campbell, J. L. (2007). Why Would Corporations Behave in Socially Responsible Ways? An Institutional Theory of Corporate Social Responsibility. Academy of Management Review, 32(3), 946-967.

Chapra, M. U. (2006). Why Has Islam Prohibited Interest? Içinde A. Thomas (Ed.), Interest in Islamic Economics: Understanding Riba (ss. 95-110). London; New York: Routledge. Geliş tarihi gönderen http://site.ebrary.com/id/10163547

Choudhury, M. A., \& Hoque, M. Z. (2019). Corporate Governance in Comparative Islamic Perspective. İçinde T. Azid, A. A. Alnodel, \& M. A. Qureshi (Ed.), Research in Corporate and Shari'ah Governance in the Muslim World: Theory and Practice. Emerald Publishing Limited.

Çizakça, M. (2011). Islamic Capitalism and Finance: Origins, Evolution and the Future. Cheltenham: Edward Elgar Publishing.

Dore, R. (2008). Financialization of the Global Economy. Industrial and Corporate Change, 17(6), 1097-1112. 
Durkheim, E. (2020). Toplumsal İşbölümü. İzmir: Cem Yayınevi.

Dünhaupt, P. (2014). An empirical assessment of the contribution of financialization and corporate governance to the rise in income inequality. Working Paper.

Emiroğlu, K., \& Aydın, S. (2003). Antropoloji sözlügü (1. basım). Ankara: Bilim ve Sanat Yayınları.

Etil, H. (2014, Mayıs). Köylünün Çerçevelenmesi: Toprak Üzerinde İşleyen Sermayenin Teknolojisi. Umran, (237), 49-56.

Fimbel, E., Binninger, A.-S., \& Karyotis, C. (2015). Demateriality: A Key Factor in the Embedding of Society within Commodification and Financialization. Society and Business Review, 10(1), 76-90. https://doi.org/10.1108/SBR-03-2014-0011

Fotopoulos, T. (1994). The Nation-State and the Market. Society and Nature, 2(2), 37.

Freeman, R. (1984). Strategic Management: A Stakeholer Perspective. Englewoods Cliffs. New Jersey: Prentice Hall.

Friedman, M. (2007). The Social Responsibility of Business is to Increase Its Profits. İçinde Corporate ethics and corporate governance (ss. 173-178). Springer.

Giddens, Anthony. (2013). Social Theory and Modern Sociology. New York, NY: John Wiley \& Sons.

Gilbert, N., \& Terrell, P. (2002). Dimensions of Social Welfare Policy. Allyn \& Bacon.

Gorz, A. (2007). Iktisadi aklın eleştirisi (I. Ergüden, Çev.). İstanbul: Ayrıntı.

Hallaq, W. (2013). The Impossible State: Islam, Politics, and Modernity's Moral Predicament. New York: Columbia University Press.

Hasan, Z. (2009). Corporate Governance: Western and Islamic Perspectives. International Review of Business Research Papers, 5(1), 277-293.

Iqbal, M. M. (2010). Prohibition of Interest and Economic Rationality. Arab Law Quarterly, 24(3), 293-308. https://doi.org/10.1163/157302510X508346

Iqbal, Z., \& Mirakhor, A. (2013). Economic Development and Islamic Finance. World Bank Publications. Jensen, M. C. (2010). Value Maximization, Stakeholder Theory, and the Corporate Objective Function. Journal of Applied Corporate Finance, 22(1), 32-42. https://doi. org/10.1111/j.1745-6622.2010.00259.x

Kosotieti, P. (1987). From Collectivity to Individualism in the Welfare State? Acta Sociologica, 30(34), 281-293.

Köse, M. (1998). İslam hukuku ve modern hukuka göre tüzel kişilik. Ekev Akademi Dergisi, 1(2), 221-230.

Kuran, T. (2004). Why the Islamic Middle East Did Not Generate an Indigenous Corporate Law. University of Southern California Law School: Law and Economics Working Paper Series 16, 1-33.

Kuran, T. (2011). The Long Divergence: How Islamic Law Held Back the Middle East. Princeton; Oxford: Princeton University Press.

Lapavitsas, C. (2014). Profiting Without Producing: How Finance Exploits Us All. London: Verso Books. Lapidus, I. M. (1990). Islamic History. Tribes and State Formation in the Middle East, 25.

Lewis, M. K. (2014). Principles of Islamic Corporate Governance. İçinde K. Hassan \& M. K. Lewis (Ed.), Handbook on Islam and Economic Life. Cheltenham: Edward Elgar Publishing. 
Lewis, V., Kay, K. D., Kelso, C., \& Larson, J. (2010). Was the 2008 Financial Crisis Caused by a Lack of Corporate Ethics? Global Journal of Business Research, 4(2), 77-84.

Mackey, A., Mackey, T. B., \& Barney, J. B. (2007). Corporate Social Responsibility and Firm Performance: Investor Preferences and Corporate Strategies. Academy of Management Review, 32(3), 817-835. https://doi.org/10.5465/amr.2007.25275676

Matsuyama, K. (2002). The Rise of Mass Consumption Societies. Journal of Political Economy, 110(5), 1035-1070. (world).

Méda, Dominique. (2012). Emek: Kaybolma Yolunda Bir Deger Mi? Istanbul: Iletisim.

Okandan, R. G. (1951). Umumi Hukuk Tarihi Dersler. İstanbul: İstanbul, İstanbul Üniversitesi Yayınları.

Orhangazi, Ö. (2008). Keynesgil Finansal Düzenlemelerden Finansallaşmaya: İktisat Literatürü ve ABD Ekonomisinin Finansallaşmasına Tarihsel Bir Bakış. ODTÜ Gelişme Dergisi, 35(1), 133-159.

Orman, S. (2015). İslam Entelektüel Geleneğinde İktisadi Boyutun Teşekkülü: Şeybânî, Serahsî ve Kitâbu'l-Kesb (II). İslam Ekonomisi ve Finansı Dergisi, 1(2), 23-67.

Öztan, B. (1994). Tüzel kişiler. Ankara: Turhan Kitabevi.

Polanyi, K. (2010). Büyük Dönüşüm: Çağımızın Siyasal ve Ekonomik Kökenleri (A. Buğra, Çev.). İstanbul: İletişim Yayınları.

Ritholtz, B. (2009). Bailout Nation: How Greed and Easy Money Corrupted Wall Street and Shook the World Economy. New Jersey: John Wiley \& Sons.

Sencal, H., \& Asutay, M. (2019). The Emergence of New Islamic Economic and Business Moralities. Thunderbird International Business Review, 61(5), 765-775.

Shiller, R. J. (2012). Finance and the Good Society. New Jersey: Princeton University Press.

Siddiqi, M. N. (2004). Riba, bank interest and the rationale of its prohibition. Jiddah, Saudi Arabia: Islamic Research and Training Institute.

Taylor, C. (2020). Modernliğin Sıkıntıları. İstanbul: Ayrıntı Yayınları.

Thornton, P. H., \& Ocasio, W. (2008). Institutional logics. The Sage handbook of organizational institutionalism, 840, 99-128.

Tönnies, F. (2019). Cemaat ve Cemiyet. İstanbul: Vakıfbank Kültür Yayınları.

Tridico, P. (2017). Inequality in Financial Capitalism. New York: Routledge.

Van Arnum, B. M., \& Naples, M. I. (2013). Financialization and Income Inequality in the United States, 1967-2010. American Journal of Economics and Sociology, 72(5), 1158-1182.

Van Der Loo, H., \& Van Reijen, W. (2014). Modernleşmenin Paradoksları (üçüncü baskı). İstanbul: İnsan Yayınları.

Wallerstein, I. M. (2014). Historical Capitalism: With Capitalist Civilization. London: Verso Books.

Zahid, A. (2013). Corporate Personality from an Islamic Perspective. Arab Law Quarterly, 27(2), 125150.

Zahraa, M. (1995). Legal Personality in Islamic Law. Arab Law Quarterly, 10(3), 193-206. 


\section{EK: Sudan Fetvası}

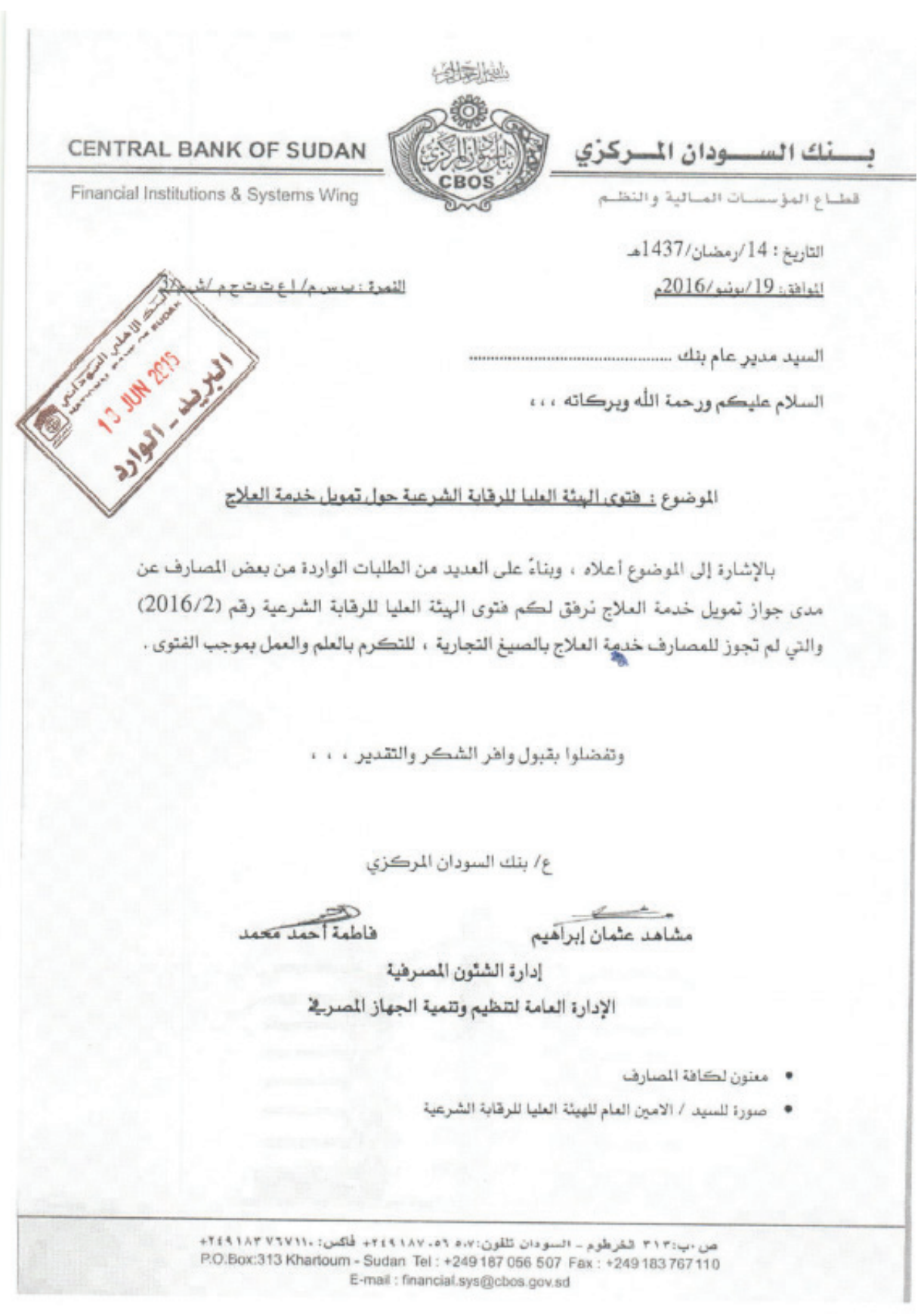


HIGH SHARIAH SUPERVISORY BOARD

FOR BANKS \& FINANCIAL INSTITUTIONS

Secretary General

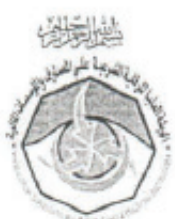

العينسة العليـا للمقتابسة الشرعيسة

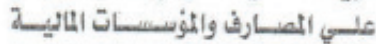
عكتب الامين العام

\section{فنتوى : رقيم (r.17/rم )}

\section{بشأن}

\section{تمويل خد هية المعلاح}

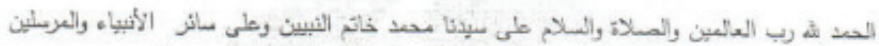

\section{وبعن: \\ الإستف:اكاء:}

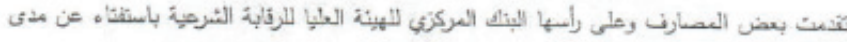

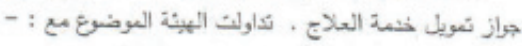

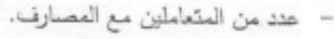

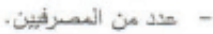

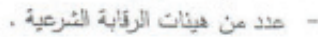

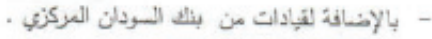

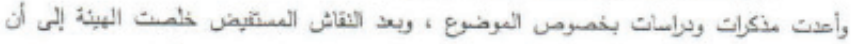

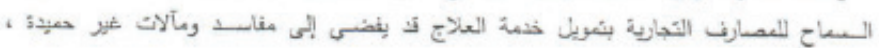

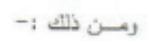

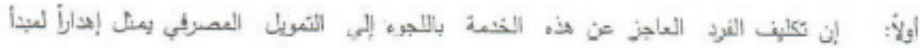

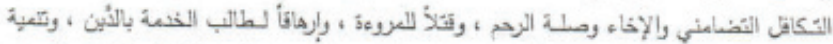

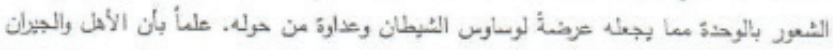

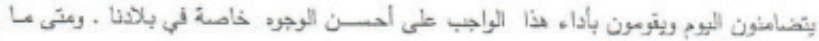

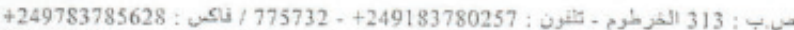

Tel : (+249) 183780257 - $775732 /$ Fax : (+249) 183785628 / P.O.Box : 313 Khartoum - Sudan Email : neimat.abdalla@ebos.gov.sd - tagwa.hassan®ebos.gov.sd 
HIGH SHARIAH SUPERVISORY BOARD FOR BANKS \& FINANCIAL INSTITUTIONS

\section{Secretary General}
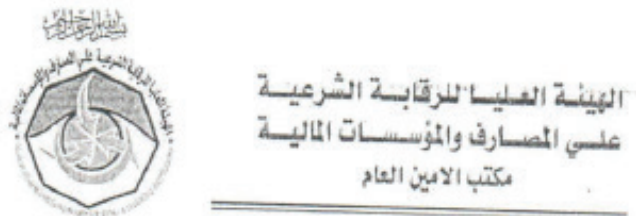

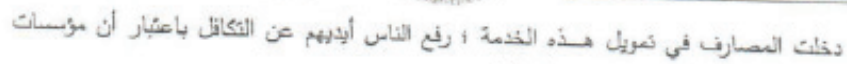

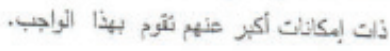

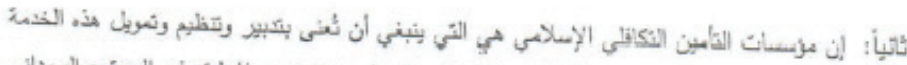

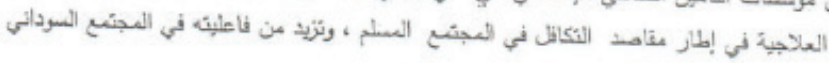

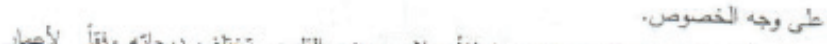

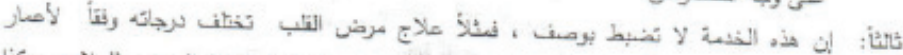

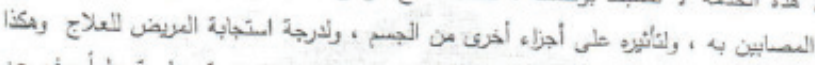

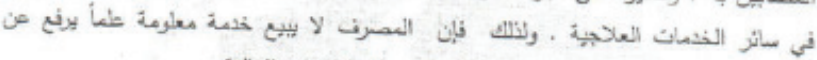

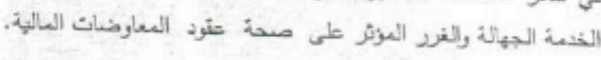

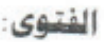

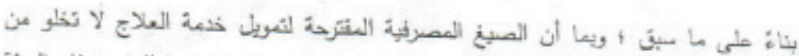

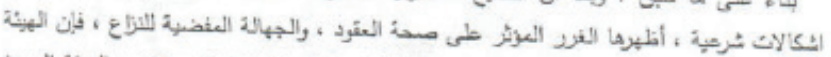

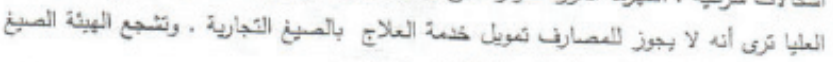

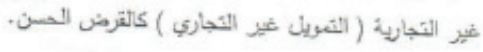

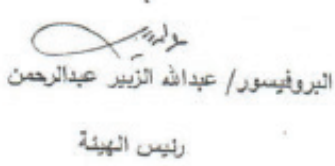

هذا وبالث التوفيق .

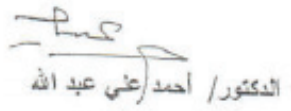

الأمبن العام

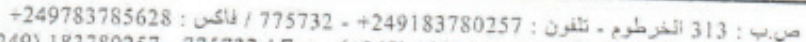

Tel : (+249) 183780257 - 775732 / Fax : $(+249) 183785628$ / P.O. Box : 313 Khartoum - Sudan Email : neimat.abdalla@ebos.gov.sd - tagwa.hassan@cbos.gov.sd 